\title{
СОЗДАНИЕ ИНБРЕДНЫХ ЛИНИЙ РЕДЬКИ ЕВРОПЕЙСКОЙ ЗИМНЕЙ НА ОСНОВЕ САМОНЕСОВМЕСТИМОСТИ
}

\author{
Косенко М.А.
}

Дан анализ селекичинных признаков коллекции редьки европейской зимней по морфологическим, фенологическим, хозяйственно-ценным признакам. Выделен ряд перспективных образцов для создания гибридов $F_{1}$ на основе самонесовместимости.

Ключевые слова: редька европейская зимняя, инбредные линии, признаки корнеплода.

Редька относится к ботаническому виду Raphanus sativus L., семейству Капустные - Brassicaceae Burnett. На период 2013 года в Госреестр включено 177 сортов, из которых 13 - редька зимняя, 5 - редька летняя, 143 - редис, 16 - лоба, и 27 гибридов F1 - редиса.

Для получения гибридов крестоцветных культур схемы селекционного процесса предусматривают использование спорофитной физиологической самонесовместимости или цитологической мужской стерильности. Высокая гомозиготность самонесовместимых родительских линий является генетической предпосылкой для беспересадочного способа производства семян F1 гибридов крестоцветных.

Использование системы самонесовместимости позволяет добиться 100\% выхода гибридных семян. Для этого необходимо создание больших коллекций чистых линий гомозиготных по аллелям гена самонесовместимости со строгим ее проявлением [1].

Многие местные сорта являются донорами ценных признаков. Например, редька зимняя (белая и черная, круглая) отличаются высокой урожайностью, повышенным содержанием сахаров и аскорбиновой кислоты, нецветушностью, способностью к длительному хранению (наилучший сорт Грайворонская).

Недостаток многих сортов редьки европейского подвида - сильная поражаемость личинками капустной мухи, особенно в Нечерноземной зоне РСФСР. Чтобы растения не поражались вредителями, необходимо развивать селекцию на скороспелость в сочетании с высокой урожайностью.

Редька европейская урожайна, холодостойка, приспособлена к условиям длинного дня и длительного хранения. Одним из проверенных способов повышения урожайности и получения однородной, качественной продукции является использование гибридной силы растения (гетерозиса).

Оценки комбинационной способности и генетические параметры количественного признака могут меняться в зависимости от условий выращивания. Эту изменчивость следует анализировать биометрико - генетическими методами и учитывать при составлении селекционных программ. Комбинационная способность характеристика родительских формы, входящей в рассматриваемую совокупность сортов, линий, клонов и т.д. по уровню изучаемого признака у ее гибридов $\mathrm{F}_{1}$ при скрещивании с другими членами совокупности. Различают общую комбинационную способность (ОКС) и специфическую комбинационную способность (СКС). 
Опыты проводили в 2013 гг. в отделе селекции ГНУ ВНИИО. По природномелиоративному районированию место исследований относится к южной лесной зоне европейской провинции в центральной части Русской равнины и входит во влажную зону.

Материалом исследований служили 21 самонесовместимых линий редьки европейской зимней, в т.ч. 5 инбредных линий отобранные и доведенные до 3 инбридинга из 4 коллекционных сортов и 16 инбредных линий отобранные и доведенные до 4 инбридинга из по пуля ции сорта Зимняя круглая черная.

Исследования проводили в питомнике исходного материала, расположенном на полях ОПХ «Быково» Раменского района, Московской области, методами лабораторно-полевых опытов, сопровождающихся сопутствующими анализами.

Посев семян в опытах проводили вручную. Технологические процессы ухода за растениями общепринятые в хозяйстве.

В процессе производства, распределения и потребления товаров и услуг происходит постоянное взаимодействие общества и природы. Природопользование существует и развивается в единстве экологических и экономических сторон, причем одна из них обусловливает другую. Характер использования природных ресурсов должен способствовать снижению затрат и повышению эффективности общественного про изводства [2].

Для выявления проявления самонесовместимости в инбредных линиях 3-4 поколения редьки европейской зимней, нами были проведены автогамные опыления цветков и гейтеногамные опыления бутонов в пределах одного растения. В результате этих опылений были выявлены растения, завязавшие при автогамном опылении цветков семена.

У инбредных линий 4-го поколения редьки европейской зимней, было определено что величина среднего числа семян в стручке от опыления цветков колебалась от 0,00 до 0,32 шт.; размах варь ирования среднего числа семян в стручке от опыления бутонов изменялась от 1,47 до 4,98 шт. Все образцы полностью самонесовместимые, уровень самонесовместимости находился в пределах 0,0 - 18,14 $\%$.

В 2013 году была отмечена положительная динамика проявления признака самонесовместимости от воздействия процесса инбридинга. В 4 поколении самонесовместимость увеличилась от 44,4 до 100\% (рисунок).

В результате оценки семенных растений редьки европейской зимней, количество завязавшихся семян от родительских линий различалось от 1,0 до 7,0 шт./стручок, гибридных семян изменялось от 1,0 до 7,0 шт./стручок. Средняя завязываемость у всех родительских линий - 4,0 шт./стручок, у гибридов - 4,4. Общее превосходство гибридов над родительскими линиями составило 9,1\%.

Проведены исследования признаков корнеплода и их изменчивости у исследуемых линий. Средняя длина корнеплода у инбредных линий 4-го поколения находилась в пределах 3,3 ..5,6 см. Средний диаметр корнеплода был от 4,8 до 6,9 см. Индекс формы корнеплода изменялся от 0,60 до 0,89 . 


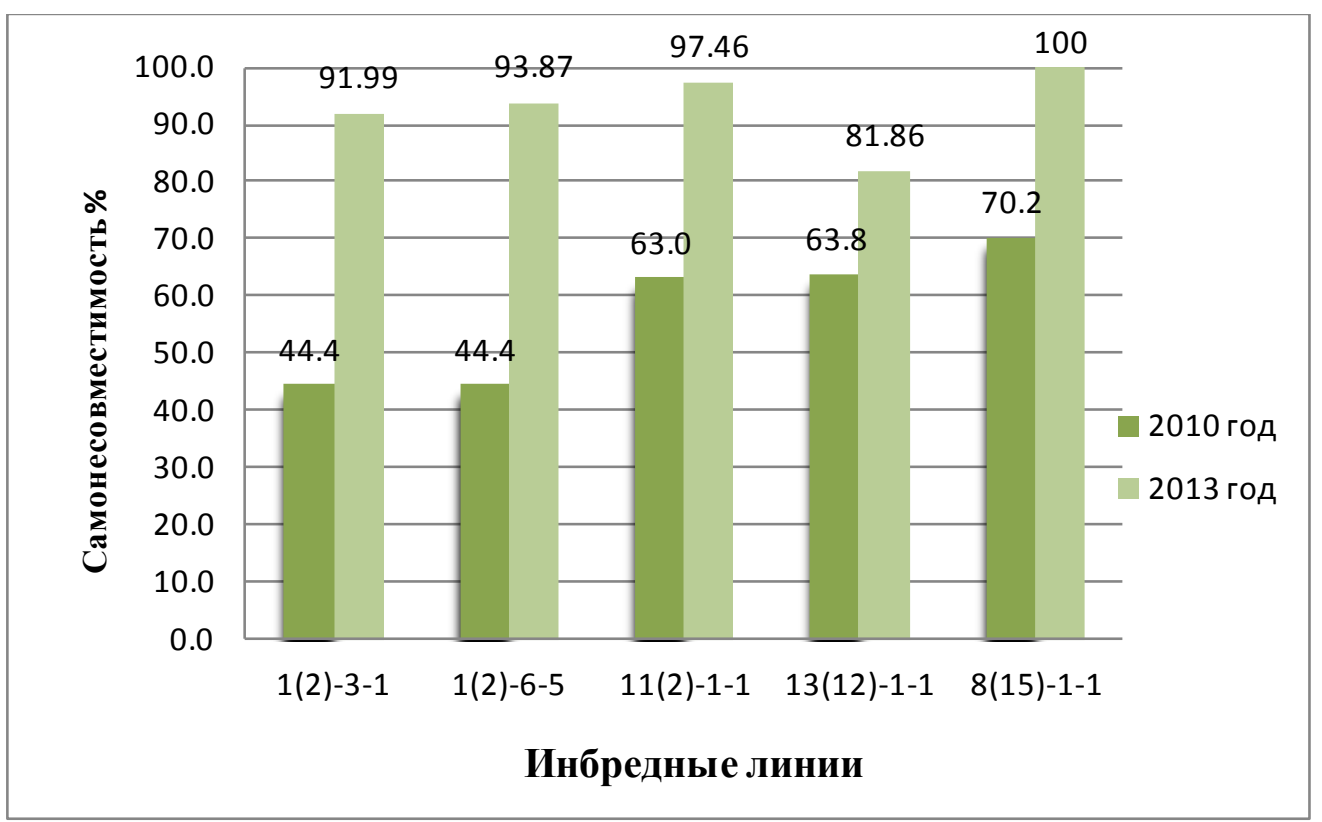

Рисунок 1 - Динамика проявления самонесовместимости в процессе инбридинга линий редьки европейской зимней, 2010 - 2013 гг.

По форме корнеплоды линий распределились на: плоскоокруглую - 77,8\%, округлоплоскую - 22,2\%. Коэффициент вариации длины корнеплода инбредных линий 3 -го поколения колебался от 5,1 до 16,0\%. Коэффициент вариации диаметра корнеплода инбредных линий 4-го поколения находился в пределах от 4,4 до 22,3\%. Коэффициент вариации индекс формы изменялся от 1,4 до 11,7\%.

Средняя длина корнеплода у инбредных линий 5-го поколения находилась в пределах 2,0...6,7 см. Средний диаметр корнеплода составил от 3,0 до 8,6 см. Индекс формы корнеплода изменялся от 0,67 до 1,06. По форме корнеплоды линий распределились на: плоскоокруглую - 71,4\%, округлоплоскую - 11,9\%, округло овальную - 2,4\%, округлую - 11,9\%, плоскую - 2,4\%,

Коэффициент вариации длины корнеплода инбредных линий 5-го поколения различался от 0,2 до 38,6\%.Коэффициент вариации диаметра корнеплода инбредных линий 5-го поколения находился в пределах от 0,2 до 40,4\%. Коэффициент вариации индекс формы изменялся от 0,40 до 16,60\%.

Урожайность инбредных линий 4-го поколения варьировала от 0,90 до 4,98

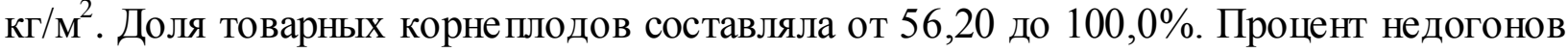
колебался от 0,00 до 44,2 \%. Больных корнеплодов не обнаружено. Число треснувших корнеплодов было от 0,0 до 39,9\%.

Средняя масса корнеплода инбредных линий 5-го поколения варьировала от 45 до 419,0 г. Урожайность инбредных линий 5-го поколения варь ировала от 0,65 до 6,29 кг/ $\mathrm{M}^{2}$. Доля товарных корнеплодов составляла от 0,0 до 100,0\%. Таким же был и уровень недогонов. Больных корнеплодов не обнаружено. Число треснувших корнеплодов было от 0,0 до $83,0 \%$.

Степень инбредной депрессии по признаку средней массы корнеплода у инбредных линий $\mathrm{I}_{4}$, редьки европейской зимней варьировала от 0,0476 до -0,7458. Депрессия отсутствовала у восьми линий.

В 2013 г. была проведена оценка гибридов F1, полученных от скрещивания 6 самонесовместимых линий редьки европейской зимней по I методу Б. Гриффинга 
(родители, прямые и реципрокные гибриды F1). Оценка проведена по длине и диаметру и урожайности корнеплода.

Средняя длина корнеплода у родительских инбредных линий находилась в пределах 3,5...5,3 см. У гетерозисных гибридов F1 изменялась от 3,0 до 6,5 см. Средний диаметр корнеплода у родительских инбредных линий находился был 4,0..7,0 см. У гетерозисных гибридов F1 изменялась от 3,0 до 8,1 см.

Индекс формы корнеплода у родительских инбредных линий изменялся от 0,71 до 1,00. У гетерозисных гибридов F1 изменялась от 0,65 до 1,00. По форме корнеплоды линий распределились на: плоскоокруглую - 83,3\%, округлую - 16,7\%. У гетерозисных гибридов F1: плоскоокруглую - 83,3\%, округлая - 3,4\%, округло-плоская $-13,3 \%$.

Коэффициент вариации длины корнеплода у родительских инбредных линий колебался от 2,0 до 19,5\%. Коэффициент вариации диаметра корнеплода инбредных линий изменялся от 3,5 до $18,7 \%$. Коэффициент вариации индекс формы изменялся от 3,46 до 10,0\%.

Коэффицие нт вариации длины корнеплода гетерозисных гибридов F1 колебался от 1,0 до 20,7\%. Коэффициент вариации диаметра корнеплода инбредных линий находился в пределах от 0,5 до $21,3 \%$. Коэффициент вариации индекс формы изменялся от 2,0 до $42,14 \%$.

Уровень товарности у родительских инбредных линий варьировал от 44,0 до $100 \%$. Уровень товарности у гетерозисных гибридов F1 составлял от 0,0 до $100 \%$. Процент недогонов изменялся от 0,0 до 100,0\%.

Доля треснутых корнеплодов была от 0,0 до 62,9\%. Масса товарного корнеплода У родительских инбредных линий варьировала от 45,0 до 184,0 г. Урожайность корнеплодов находилась в пределах от 0,68 до 2,77 кг/м².

Масса товарного корнеплода у гетерозисных гибридов F1 изменялась от 70,0 до 313,0 г. Урожайность корнеплодов различалась от 1,05 до 4,7 кг/ $\mathrm{M}^{2}$.

Показатель эффекта ОКС по признаку «средняя длина корнеплода» изменялся от 3,5 до 5,5 см. Средняя длина у всех родителей - 4,48 см, гибриды - 5,03 см. Общее превосходство гибридов над родительскими линиями составило 12,1\%.

Показатель материнского эффекта варьировал от -0,47 до 0,50. Его определение необходимо при селекции гибридов F1 перекрестноопыляемых растений на базе самонесовместимости, когда гибридные семена собирают с обеих родительских линий вместе. В этом случае важно, чтобы величина реципрокного эффекта была, возможно, меньше, так как его наличие приводит к пестроте гибридов. Показателем реципрокного эффекта по признаку «средняя длина корнеплода» варьировал от $-1,20$ до 0,45 .

Диаметр корнеплода F1 гибридов редьки европейской зимней. различался от 3,0 до 8,1 см. Средний диаметр у всех родителей - 5,62 см, у гибридов - 6,55 см. Общее превосходство гибридов над родительскими линиями составило 16,56\%.

Изучение специфической комбинационной способности показало, что различия СКС по признаку «средний диаметр корнеплода» существенны. Показателем реципрокного эффекта по признаку «средний диаметр корне плода» варь ировал от -1,90 до 0,85 .

Нами был рассчитана урожайность корнеплодов F1 гибридов редьки европейской зимней. Этот показатель составил от 0,675 до 4,695 кг/ $\mathrm{m}^{2}$. Средняя

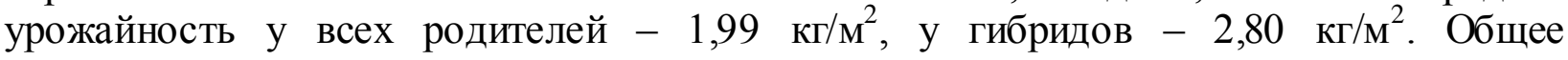
превосходство гибридов над родительскими линиями составило $41,1 \%$. 
Показатель материнского эффекта ОКС по признаку «средняя урожайность корнеплода» изменялся от $-0,65$ до 0,06. Показатель реципрокного эффекта по признаку «урожайность корнеплодов» различался от -1,16 до 1,16. Показатель средней массы корнеплода у родительских линий варьировал от 45,0 до 184,0 г, у гибридов изменялся от 70,0 до 313 г.

Было определено проявление эффектов гетерозиса у гибридов первого поколения редьки европейской зимней. В некоторых гибридных комбинациях происходило отрицательное проявление гетерозиса, или незначительное превышение над родительскими показателями средней массы корнеплода. Он варьировал от 50,0 до $108,8 \%$.

Средняя масса у всех родителей - 0,133 кг, у гибридов - 0,191 кг. Общее превосходство гибридов над родительскими линиями составляет- 44,5\%. Результаты анализа линий по ОКС и СКС позволяют отобрать наиболее подходящие из них. В дальнейшем они могут послужить исходным материалом для создания популяций, либо высокогетерозиготных гибридов F1.

Линии, обладающие по ряду признаков высокой ОКС могут быть вовлечены в селекционный процесс для создания гетерозисных гибридов. Эти линии могут быть использованы как компо ненты популяций.

\title{
Литература
}

1. Монахос Г.Ф. Схема создания двухлинейных гибридов капустных овощных культур на основе самонесовместимости // Изв. ТСХА, 2007. Вып.2. с.86 $-93$.

2. Косенко Т.Г. Рациональное использование природных ресурсов в сельскохозяйственном производстве. Учебное пособие. п.Перс иановский. 2007.114 c.

\section{CREATION OF INB REED LINES OF THE RADISH EUROPEAN WINTER ON THE B ASIS OF SELF-INCOMPATIBILITY}

\author{
Kosenko M. A.
}

The analysis of selection signs of a collection of a radish European winter on morphological, phenological, economic and valuable features is given. Identified a number of perspective samples for creation hybrids of F1 on the basis of selfincompatibility is allocated.

Keywords: radish European winter, inbredny lines, root crop signs.

Косенко Мария Александровна - к.с.-Х. Н., старший научный сотрудник отдела селекции ГНУ ВНИИО, д. Верея, Раменский район, Московская обл. 